\title{
Combustion Characteristics of CI Engine Running with Biodiesel Blends
}

\author{
B. Tesfa. R. Mishra, F. Gu, A. D. Ball \\ Computing and Engineering, University of Huddersfield, \\ Queensgate, Huddersfield, HD1 3DH, UK \\ +44 (0) 1484 471193, b.c.tesfa@ hud.ac.uk; +44 (0) 1484 473263,r.mishra@hud.ac.uk, \\ +44 (0) 1484 472596, f.gu@ @ud.ac.uk; +44 (0) 1484 472438, andrew.ball@ hud.ac.uk
}

\begin{abstract}
Biodiesel is one of the promising renewable, alternative and environmentally friendly biofuels that can be used in diesel engine with little or no modification in the engine. In the present study an experimental investigation has been carried out on the combustion and performance characteristics of a CI engine running with biodiesel under steady state operating conditions. The experimental work has been conducted on a four-cylinder, four -stroke, direct injection (DI) and turbocharged diesel engine. In this investigation, biodiesel (produced from the waste oil by transesterfication process) and normal diesel have been used. During the experiment the incylinder pressure and the specific fuel consumption were measured. The experimental results of this study can be summarised as follows. The tests on engine running with different fuels (biodiesel and diesel) have resulted in almost overlapping P-V diagrams. The power output values at 1300rpm and at 105, 210, 315 and $420 \mathrm{Nm}$ torque values for both the diesel and biodiesel fuels are almost the same. The engine running with biodiesel has produced slightly higher incylinder pressure and peak heat release rate than the engine running with normal diesel at all operating conditions. Furthermore, the brake specific fuel consumption values for the engine running with biodiesel are higher than the engine running with normal diesel by a maximum of $14 \%$. However, the thermal efficiency of the engine running with biodiesel is lower than engine running by diesel by $10 \%$.
\end{abstract}

Key words: combustion characteristics, brake specific fuel consumption, thermal efficiency

\section{Introduction}

A large number of studies have shown that biodiesel is one of the promising renewable, alternative and environmentally friendly biofuels that can be used in diesel engine with little or no modification in the engine [1-5]. The stringent emission laws, the depletion of fossil fuels and relation of fuels with politics have forced the world to find alternatives to fossil fuels. Numerous vegetable oil esters (biodiesel) have been investigated for use in internal combustion engines and have been shown to have higher potential to reduce $\mathrm{CO}_{2}$ emission [6], [7] . The effects of different fuels on the performance characteristics of engines have been extensively reported. The common engine parameters on which effects have been quantified include: brake specific fuel consumption, brake effective power and thermal efficiency. Many researchers have compared the performance of engines running with biodiesel and its blends with engines running with normal diesel. It has been reported by a large number of researchers that the use of biodiesel results in have higher brake specific fuel consumption and higher thermal efficiency than the use of diesel in an engine [8-11].

However, use of different biodiesels in an engine results in variability in engine performance and emission due variation in physical and chemical characteristics of the biodiesel [12]. The effects of these physio-chemical properties on fuel supply system such as fuel pump, fuel filter and air-fuel mixing cylinder have already been reported [13]. To improve the performance and emission characteristics of the engine running with biodiesel and to understand the effects of physical properties of the fuel on the engine performance and emissions a detailed investigation is required on the underlying combustion and heat release characteristics. The heat released and resulting pressure and temperature fields affect the performance and emission characteristics most however most of the researchers so far have correlated the performance and emission characteristics of biodiesel against test parameters such as biodiesel fraction blend, engine-speed, engine load, injection timing, injection pressure and engine compression ratio. However, there are very few works that have been reported on the engine combustion characteristics and heat release phenomena corresponding to different biodiesels and its blends [14]. Therefore, the objective of this study is to investigate the performance, combustion characteristics and heat release rate phenomena of a compression ignition engine running with biodiesel and biodiesel blends. 


\section{Description of Biodiesel Properties}

The fuels used in this study were produced from the waste oil by transesterfication process using methanol and the normal diesel fuel was obtained from a local fuel supplier. The waste oil biodiesel was blended with diesel to produce $50 \%$ biodiesel (50B) on volume basis. Three types of fuels were used in the tests $(50 \mathrm{~B}, 100 \mathrm{~B}$, and diesel).The main physical properties of the pure and blended fuels were measured in the Applied Science Laboratory, University of Huddersfield and are listed in Table 1.

Table 1 Physical and chemical properties of biodiesel and its blends

\begin{tabular}{|l|l|l|l|l|}
\hline Property & & Diesel & 50B & 100B \\
\hline & $\mathrm{C}$ & 87 & 82 & 77 \\
\hline Composition, \% & $\mathrm{H}$ & 13 & 12.5 & 12 \\
\hline & $\mathrm{O}$ & 0 & 5.5 & 11 \\
\hline Density, $\mathrm{kg} / \mathrm{m}^{3}$ & & 853 & 866 & 879 \\
\hline $\mathrm{LHV}^{*}, \mathrm{KJ} / \mathrm{Kg}$ & & 42679 & 40589.5 & 38500 \\
\hline Viscosity, $\mathrm{mm}^{2} / \mathrm{s}$ & & 3.55 & 4.3 & 5.13 \\
\hline
\end{tabular}

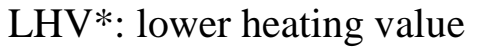

\section{Experimental Facilities and Test}

\section{Procedures}

The experiments were performed using a four-cylinder, four stoke, direct injection (DI), turbocharged diesel engine. The engine setup includes a transient test unit with 200kW AC Dynamometer 4 Quadrant Regenerative Drive with Motoring and Absorbing Capability. It is integrated with speed sensors, pressure transducers, thermocouples, air flow metres, fuel flow metres and inline torque meter. The basic characteristics of the engine are described in Table 2 and the detailed layout of the experimental facilities is described in figure 1 .

The engine is integrated with state of the art performance and emission measurement facilities. The engine is fully instrumented, and the steady state and transient cycle can be programmed with the CADET software integrated with the engine system. To measure the cylinder pressure PMP 4000 series transducer with measuring range of $70 \mathrm{mbar}$ to $700 \mathrm{mbar}$ was used.The steady processes were programmed using CADET program and in the present study the engine load was varied from $105 \mathrm{Nm}$ to $420 \mathrm{Nm}$ and the engine was maintained at 900, 1100, 1300, 1500, 1700, and $1900 \mathrm{rpm}$ respectively.

During the tests, fuel lines were drained prior to filling them with the next fuel blend. The engine was run with new filled fuel for 10 minutes without taking data. This is done to ensure that fuel from previous measurements remaining in flow meter, fuel filter and fuel pipes has been removed. Furthermore in between each type of biodiesel blend test, a preconditioning procedure of high speed and high load operation was employed in order to purge any of the remaining previously tested fuel from the engine fuel system and to remove the deposited hydrocarbon from the sample line. The frequency of the data acquisition system was $37 \mathrm{kHz}$ and the sampling time $\begin{array}{llll}\text { used } & \text { was } & 60 & \text { seconds. }\end{array}$

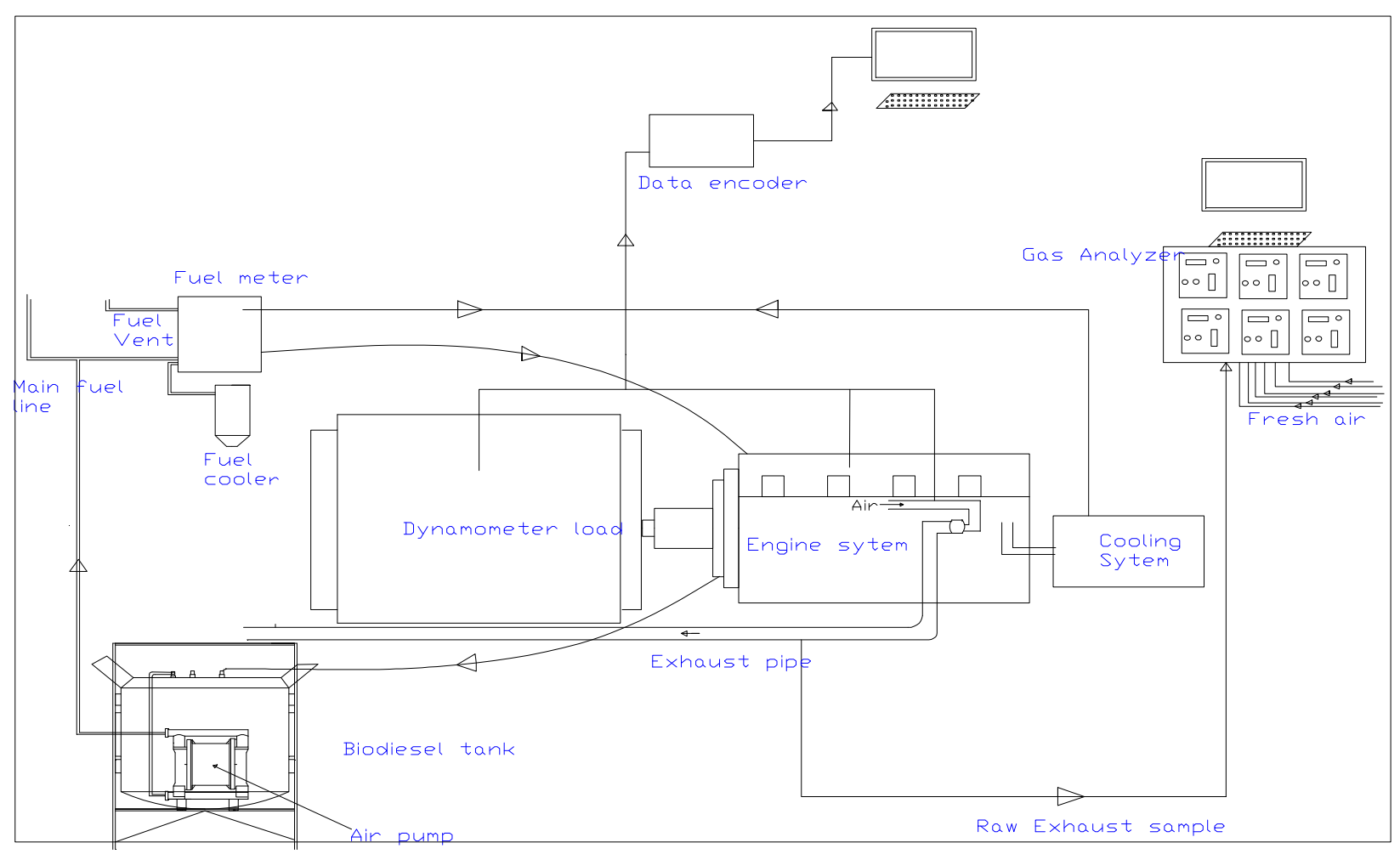

Figure 1 Experimental setup 
Table 2 Characteristics of engine

\begin{tabular}{|l|l|}
\hline Engine type & Turbo charged diesel engine \\
\hline Number of cylinders & 4 \\
\hline Bore & $103 \mathrm{~mm}$ \\
\hline Stroke & $132 \mathrm{~mm}$ \\
\hline Compressor inlet diameter & $60 \mathrm{~mm}$ \\
\hline Compressor outlet diameter & $60 \mathrm{~mm}$ \\
\hline Compression ratio & 18.3 \\
\hline Number of valves & 16 \\
\hline Injection system & Direct injection \\
\hline Displacement & 4.399 litre \\
\hline Cooling system & Water \\
\hline Recommended speed & $850 \mathrm{rpm}$ \\
\hline Maximum power & $74.2 \mathrm{Kw} @ 2200 \mathrm{rpm}$ \\
\hline
\end{tabular}

\section{Estimation of Heat Release Rate from Experiment}

The heat release rate (HRR) is an important parameter to analysis the combustion phenomena in the engine cylinder. The important combustion phenomena parameters such as combustion duration and intensity can be easily estimated from the heat release rate diagram. The HRR diagram also provides key input parameters in the modelling of the NOx emission. The heat release rate is modelled by applying the first law of thermodynamics. The simplified model is shown in equation (1).

$$
\frac{d Q}{d \theta}=p \cdot \frac{\gamma}{\gamma-1} \frac{d V}{d \theta}+\frac{1}{\gamma-1} V \frac{d P}{d \theta}
$$

Where $d Q / d \theta$ is rate of heat release $(\mathrm{kJ} / \mathrm{deg}), P$ is the incylinder gas pressure, $V$ is in-cylinder pressure, and $\gamma$ is the ratio of specific heats

In the equation (1), the cylinder content is assumed to be homogeneous mixture of air and combustion products. It is further assumed that a uniform temperature and pressure exist at any moment during the combustion process. To determine the HRR of the internal combustion engine by equation (1), the engine geometry specification that has been used is described in table 1 and the cylinder pressure that were recorded during the tests were used. Furthermore, the cumulative heat release $\left(\mathrm{Q}_{\text {cum }}\right)$ in combustion cylinder is found by equation (2).

$$
Q c u m=\int d Q=\int P \frac{\gamma}{\gamma-1} d V+\frac{1}{\gamma-1} V d P
$$

\section{Discussion and Results}

The main aim of the present study is to investigate the combustion and performance characteristics of compression ignition engine running with biodiesel and its blends. In the following, results are presented for all the test conditions and efforts have been made to bring out the effects of different blends on combustion characteristics and engine performance.

\subsection{Cylinder Pressure and Heat release rate of the CI engine}

Figure 2 depicts that $\mathrm{P}-\mathrm{V}$ diagram of compression ignition engine, which was examined at 1300rpm engine speed and at $105,210,315$ and $420 \mathrm{Nm}$ engine load conditions. The results show that the power, which is produced by the engine cylinder and is calculated from the P-V diagram does not show any significant change for different fuels namely $50 \mathrm{~B}, 100 \mathrm{~B}$ and pure diesel at different engine loads of 105, 210, 315Nm and 420Nm. This indicates that the biodiesel's lower heating value effect is compensated by the combustion related effects.

Figure 3 shows that the in-cylinder pressure within the combustion chamber of the CI engine running with 100B, $50 \mathrm{~B}$ and normal diesel at a speed of $1300 \mathrm{rpm}$ and engine loads of $105 \mathrm{Nm}, 210 \mathrm{Nm}, 315 \mathrm{Nm}$ and $420 \mathrm{Nm}$. The results show that the peak cylinder pressure of the engine running with biodiesel is slightly higher than the engine running with diesel. The main cause for higher peak incylinder pressure in the CI engine running with biodiesel is because of the advanced combustion process initiated by easy flow-ability of bio-diesel due to the physical properties of biodiesel. In addition, due to the presence of oxygen molecule in biodiesel, the hydrocarbons achieve complete combustion [14], [15] resulting in higher incylinder pressure. The effect of the load on the cylinder pressure has also been investigated and the results are shown in Figure 4. It can be seen that the in-cylinder pressure increases with increasing load for both diesel and biodiesel blends. 

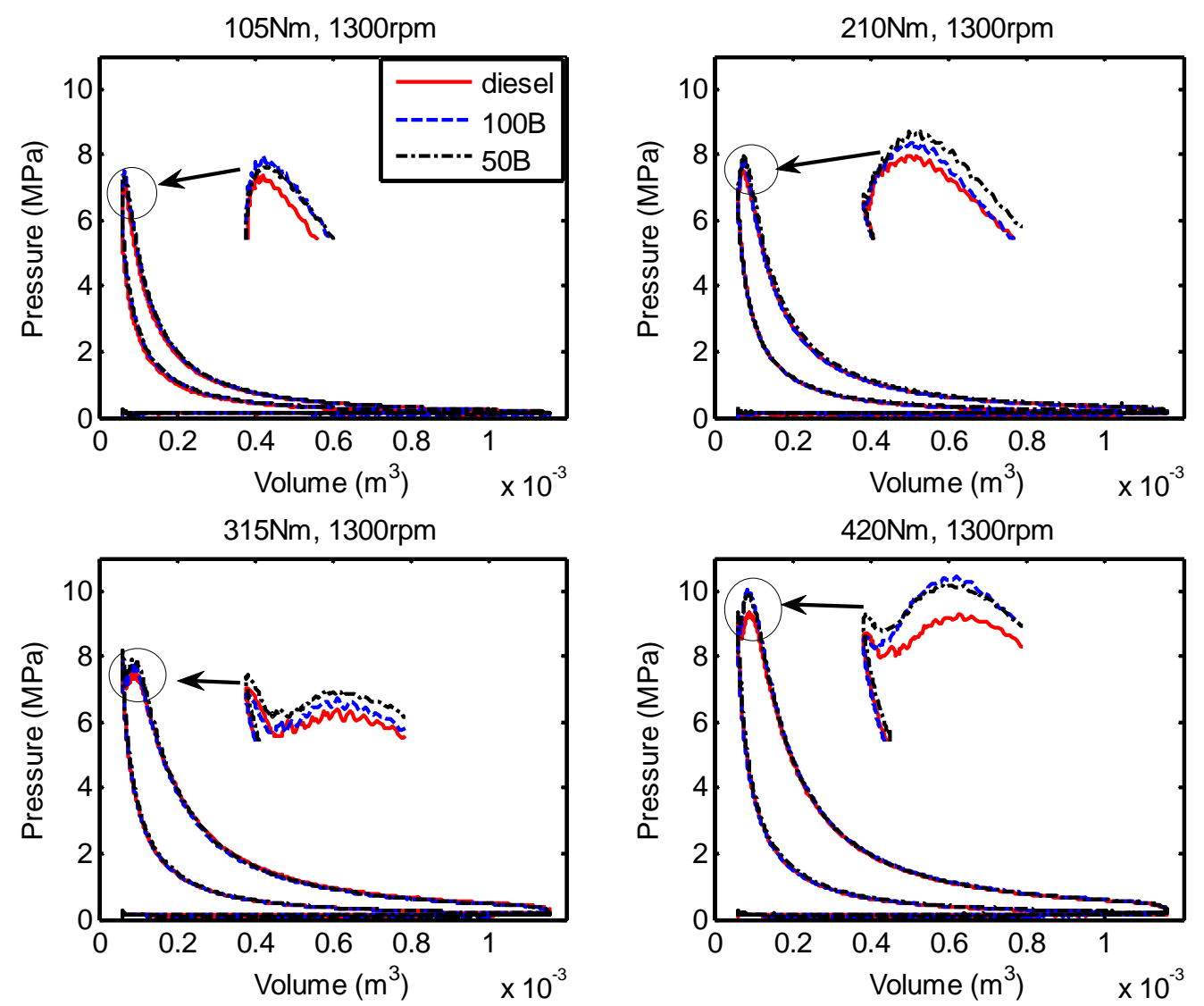

Figure $2 \mathrm{P}-\mathrm{V}$ diagram under different working conditions

(a) $1300 \mathrm{rpm} 105 \mathrm{Nm}$

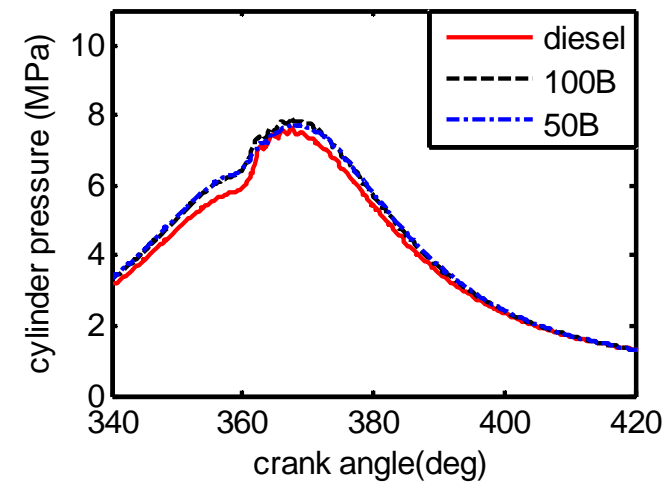

(c) $1300 \mathrm{rpm} 315 \mathrm{Nm}$

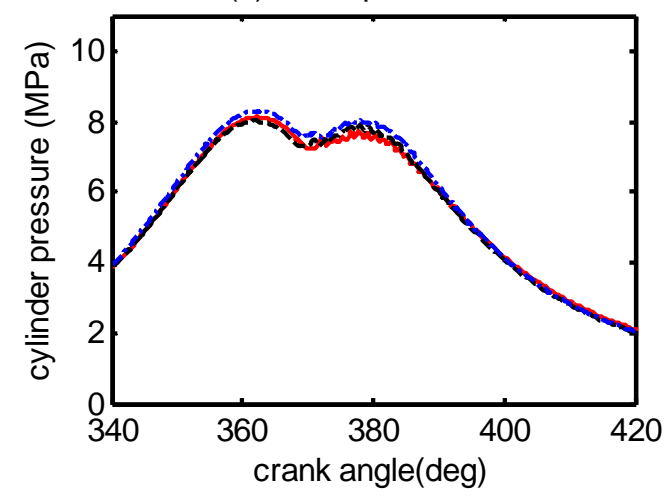

(b) $1300 \mathrm{rpm} 210 \mathrm{Nm}$

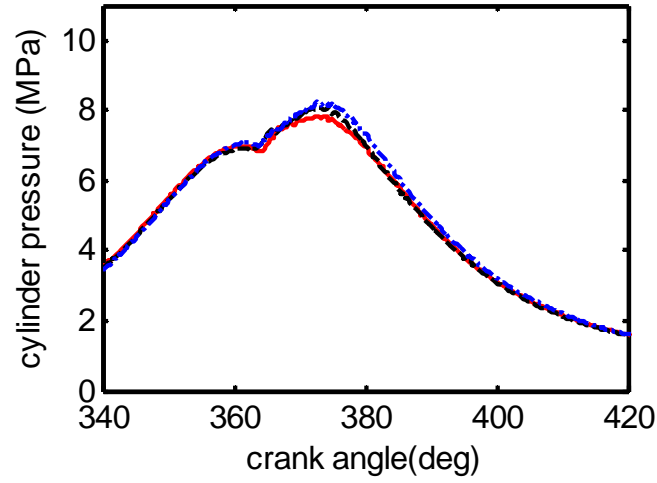

(d) $1300 \mathrm{rpm} 420 \mathrm{Nm}$

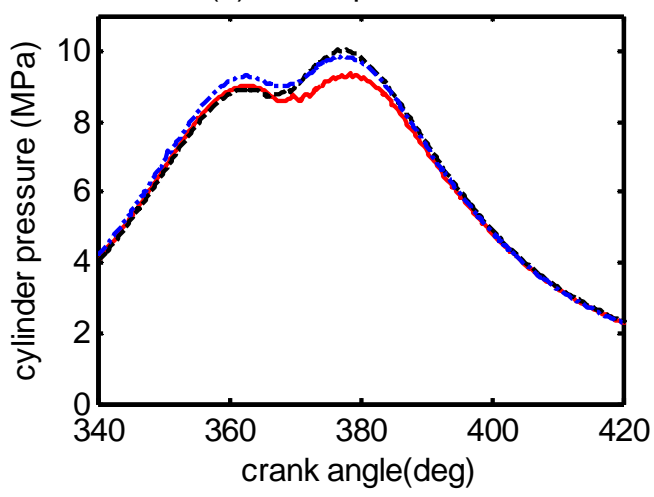

Figure 3 Comparison of in-cylinder pressure for 50B, 100 and diesel 
(a) diesel at speed 1300rpm

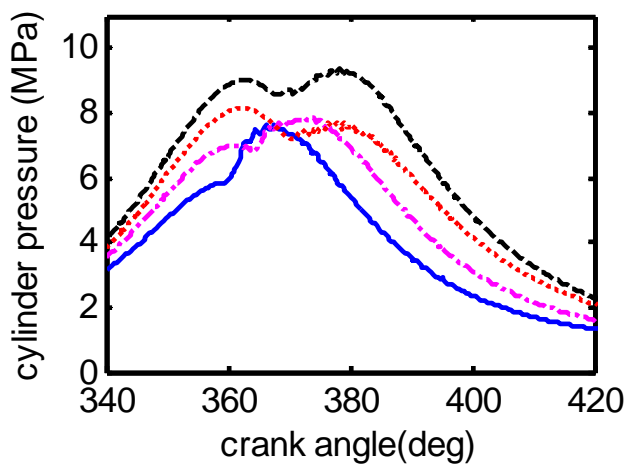

c) $050 \mathrm{~B}$ at speed $1300 \mathrm{rpm}$

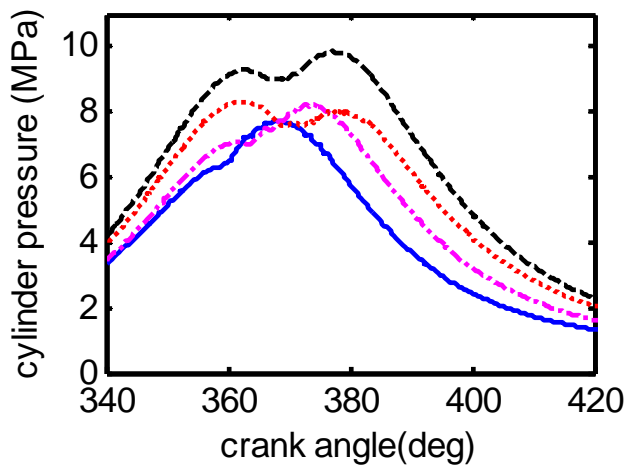

(b) $100 \mathrm{~B}$ at speed $1300 \mathrm{rpm}$

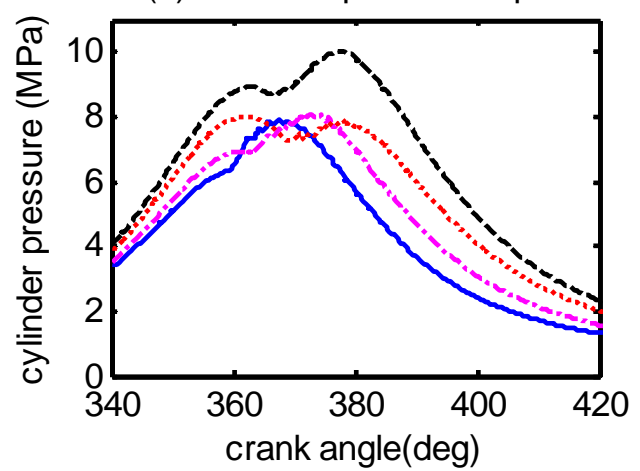

Figure 4 Effects of load on in-cylinder pressure for 50B, 100B and diesel

Figure 5(a) shows that the heat release rates for CI engine running with biodiesel blends and normal diesel for a speed of $1300 \mathrm{rpm}$ and at load values of $105 \mathrm{Nm}$ and $420 \mathrm{Nm}$. It can be seen that the CI engine running with biodiesel has a higher peak in the heat release rate diagram than the diesel. This phenomenon can be explained on the basis of the presence of the oxygen molecule in biodiesel fuel that results in the air-mixed fuel in the cylinder to burn completely and increase the heat release rate. The cumulative heat release for the diesel, 50B and 100B is shown in figure 5(b) and it can be seen that the biodiesel blend (50B) has higher cumulative heat release.

(a) $1300 \mathrm{rpm} 420 \mathrm{Nm}$

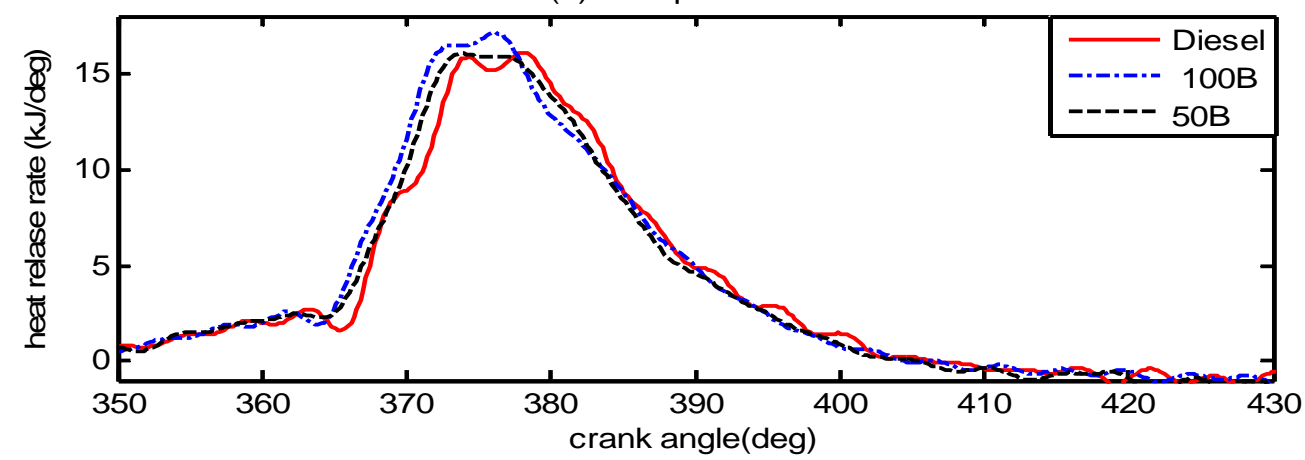

(b) $1300 \mathrm{rpm} 420 \mathrm{Nm}$

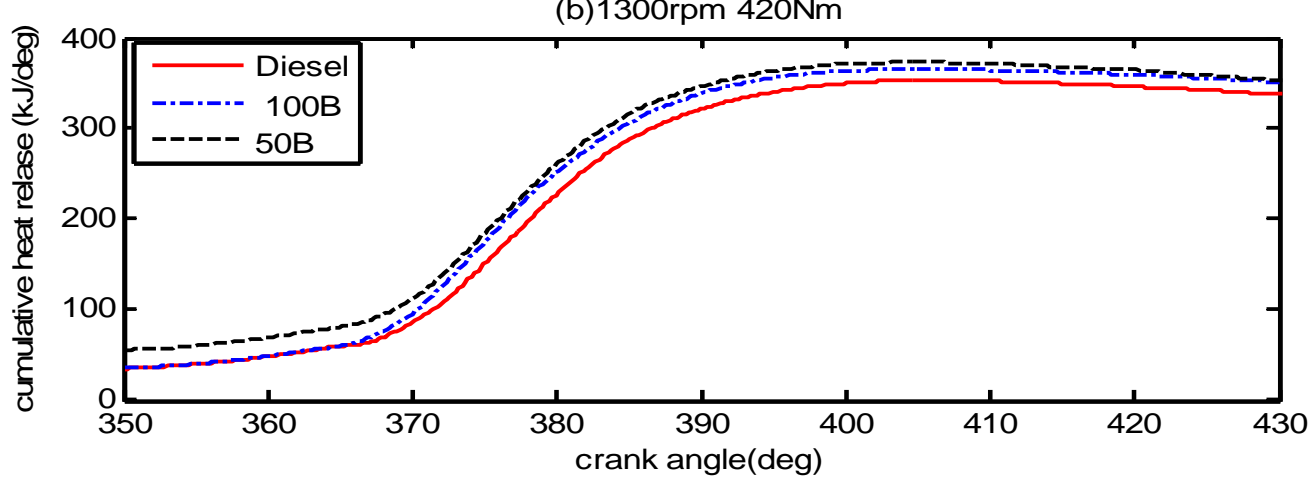

Figure 5 (a) Heat release rate versus crank angle for different biodiesel blends ,(b) Cumulative heat release for biodiesel blends 


\subsection{Brake specific fuel consumption and Thermal efficiency}

The brake specific fuel consumption (bsfc) is estimated from the brake power output of the engine and the mass flow rate of the fuel. It is an important parameter to analyse the performance of the engine and fuel efficiency. Figure 6 shows the variation of the bsfc corresponding to $50 \mathrm{~B}, 100 \mathrm{~B}$ and normal diesel against engine speed at loads of $105 \mathrm{Nm}$ and $420 \mathrm{Nm}$. At lower load $(105 \mathrm{Nm})$ the bsfc corresponding to $50 \mathrm{~B}$ and $100 \mathrm{~B}$ is higher by a magnitude of $10 \%$ and $15 \%$ respectively as compared to bsfc corresponding to normal diesel. However, at higher load $(420 \mathrm{Nm})$ the bsfc increase corresponding to biodiesel blends is fairly small (up to $5 \%)$.

Furthermore, the thermal efficiency of the engine using biodiesels used in the present investigation (50B, 100B) and the diesel fuel has been computed for different engine speeds at two different load conditions (lower load and higher load) and has been shown in Figure 7. The brake thermal efficiency is calculated from of bsfc and lower heating value by the equation given below.

$$
\eta=\frac{3600}{\operatorname{sfr} \times \operatorname{llh} v} \times 100 \%
$$

Where $\boldsymbol{\eta}$ is the thermal efficiency (\%), sfc is brake specific fuel consumption $(\mathrm{g} / \mathrm{kWh})$ of the biodiesel and $l h v$ is lower heating value $(\mathrm{kJ} / \mathrm{kg})$ of the biodiesel.

It can be observed from Figure 7 that at low loads, the engine brake thermal efficiency when using biodiesel blends is lower as compared to the normal diesel, but at higher loads, the efficiency corresponding to biodiesel blends are higher than that corresponding to normal diesel.
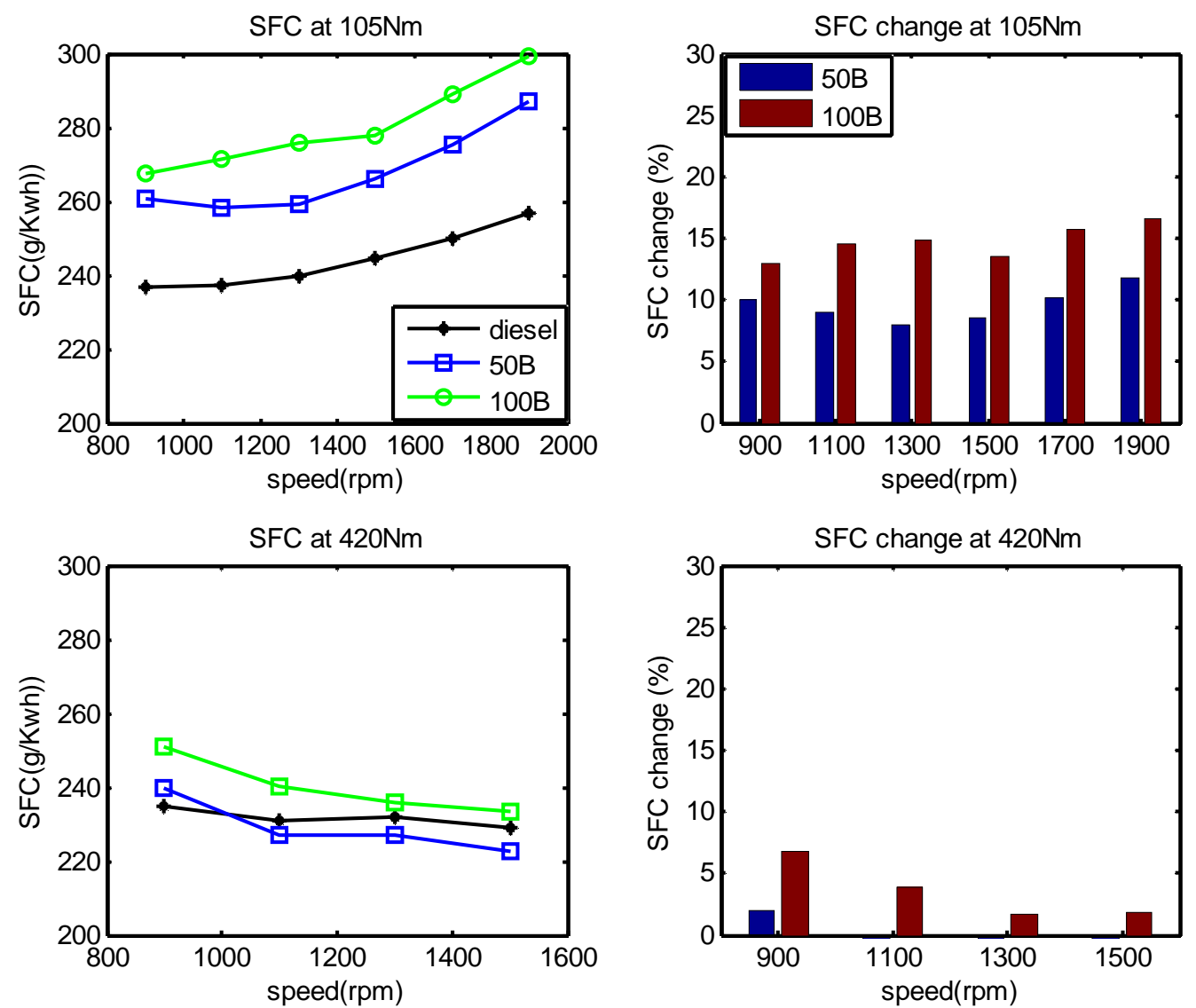

Figure 6 BSFC of CI engine running with 50B, 100B and diesel and its \% deviation from diesel 
(a) thermal efficency at $105 \mathrm{Nm}$

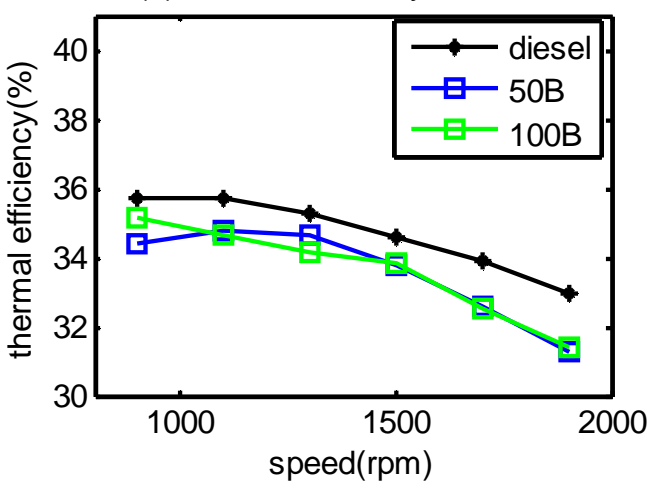

(c) thermal efficency at $420 \mathrm{Nm}$

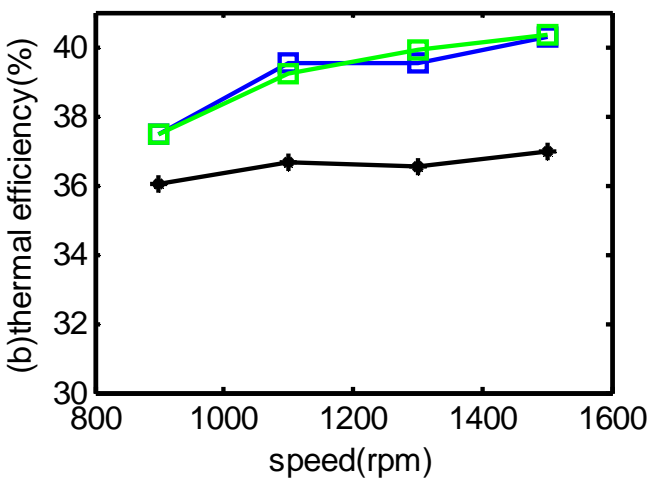

(b) thermal efficency change at $105 \mathrm{Nm}$

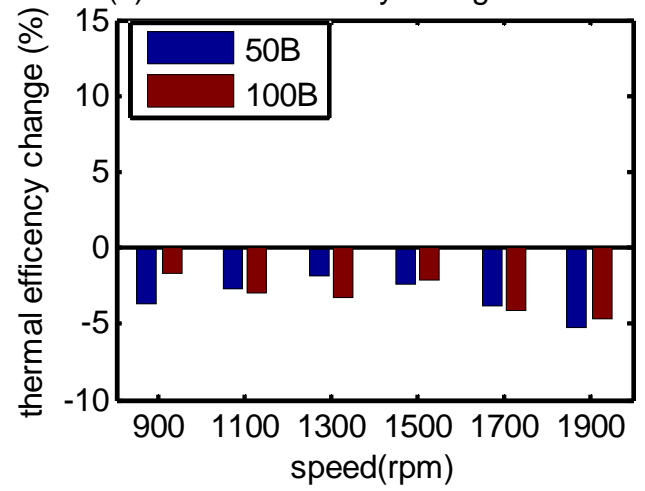

(d) thermal efficency change at $420 \mathrm{Nm}$

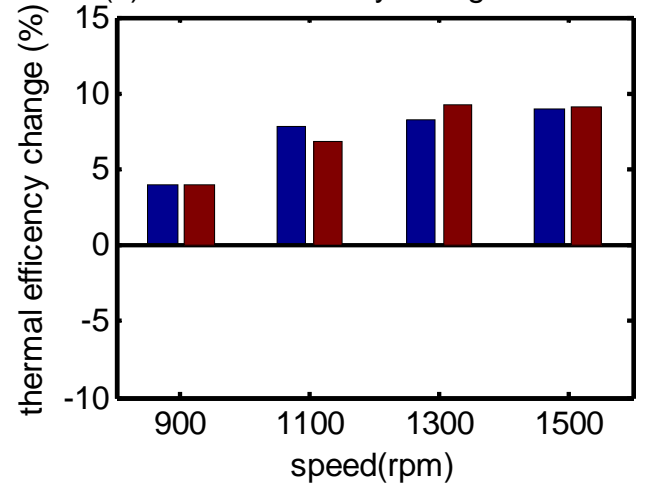

Figure 7 Thermal efficiency of CI engine running with 50B, 100B and diesel and its \% deviation from diesel

\section{Conclusion}

In the present study experimental investigations have been carried out on a compression ignition (CI) engine using blends of biodiesel and diesel fuels under steady state operating conditions. The experimental results of this study can be summarised as follows.

1. The tests on engine running with different fuels (biodiesel and diesel) have resulted in almost overlapped $\mathrm{P}-\mathrm{V}$ diagrams. The power output values at $1300 \mathrm{rpm}$ and at 105, 210, 315 and $420 \mathrm{Nm}$ torque values for both the diesel and biodiesel fuels are almost the same. The engine running with biodiesel has produced slightly higher in-cylinder pressure and peak heat release rate than the engine running with normal diesel at all operating conditions.

2. The brake specific fuel consumption and thermal efficiency values for the engine running with biodiesel are higher than the engine running with normal diesel by a maximum of $15 \%$ and $10 \%$ respectively.

\section{References}

[1] G. Hammond, S. Kallu, and M. McManus, "Development of biofuels for the UK automotive market," Applied Energy, vol. 85, no. 6, pp. 506-515, Jun. 2008.

[2] M. Lapuerta, O. Armas, R. Ballesteros, and J. Fern $\square$ ndez, "Diesel emissions from biofuels derived from Spanish potential vegetable oils," Fuel, vol. 84, no. 6, pp. 773-780, Apr. 2005.

[3] T. Durbin, J. Collins, J. Norbeck, and M. Smith, "Effects of Biodiesel, Biodiesel Blends, and a Synthetic Diesel on Emissions from Light Heavy-Duty Diesel Vehicles," Environmental Science \& Technology, vol. 34, no. 3, pp. 349-355, Feb. 2000.

[4] Daniel Puppan, "Environmeental Evaluation of Biofules," 16-Jun-2008. [Online]. Available: http://www.pp.bme.hu/so/2002_1/pdf/so2002_1_08.pdf. [Accessed: 16-Jun-2008].

[5] A. Ramadhas, C. Muraleedharan, and S. Jayaraj, "Performance and emission evaluation of a diesel engine fueled with methyl esters of rubber seed oil," Renewable Energy, vol. 30, no. 12, pp. 1789-1800, Oct. 2005.

[6] M. P. Dorado, E. Ballesteros, J. M. Arnal, J. G $\square$ mez, and F. J. L $\square$ pez, "Exhaust emissions from a Diesel engine fueled with transesterified waste olive oil[small star, filled]," Fuel, vol. 82, no. 11, pp. 1311-1315, Jul. 2003.

[7] Z. Utlu and M. S. Ko $\square$ ak, "The effect of biodiesel fuel obtained from waste frying oil on direct injection diesel engine performance and exhaust emissions," Renewable Energy, vol. 33, no. 8, pp. 1936-1941, Aug. 2008.

[8] M. Lapuerta, O. Armas, R. Ballesteros, and J. Fernández, "Diesel emissions from biofuels derived from Spanish potential vegetable oils," Fuel, vol. 84, no. 6, pp. 773780, Apr. 2005.

[9] M. Lapuerta, O. Armas, and J. Rodríguez-Fernández, "Effect of biodiesel fuels on diesel engine emissions," Progress in Energy and Combustion Science, vol. 34, no. 2, pp. 198-223, Apr. 2008.

[10] D. AltIparmak, A. Keskin, A. Koca, and M. G $\square \mathbf{r} \square$, "Alternative fuel properties of tall oil fatty acid methyl ester-diesel fuel blends," Bioresource Technology, vol. 98, no. 2, pp. 241-246, Jan. 2007. 
[11] A. Monyem and J. H. Van Gerpen, "The effect of biodiesel oxidation on engine performance and emissions," Biomass and Bioenergy, vol. 20, no. 4, pp. 317-325, Apr. 2001

[12] Y. Gao et al., "Experimental study of the spray characteristics of biodiesel based on inedible oil," Biotechnology Advances, vol. 27, no. 5, pp. 616-624, Sep. .

[13] B. Tesfa, R. Mishra, F. Gu, and N. Powles, "Prediction models for density and viscosity of biodiesel and their effects on fuel supply system in CI engines," Renewable
Energy, vol. 35, no. 12, pp. 2752-2760, Dec. 2010.

[14] M. Gumus, "A comprehensive experimental investigation of combustion and heat release characteristics of a biodiesel (hazelnut kernel oil methyl ester) fueled direct injection compression ignition engine," Fuel.

[15] M. Canakci, "Combustion characteristics of a turbocharged DI compression ignition engine fueled with petroleum diesel fuels and biodiesel," Bioresource Technology, vol. 98, no. 6, pp. 1167-1175, Apr. 2007. 